\title{
„Recikliranje“ prostora kroz prošlost Dalmacije (očima konzervatora)
}

Ivan Alduk

DOI: $10.17234 / 9789531757232-09$

Diljem Dalmacije postoje bezbrojni više ili manje poznati primjeri ponovnog korištenja jednog istog prostora kroz povijest. Od već svima poznatog naslova splitskog pjesnika Jakše Fiamenga - I palača rodi grad - do stotine više ili manje poznatih prostora čija bi se povijest teško obuhvatila i tekstom znatno većim od ovoga. Neki od tih prostora gotovo čitavo svoje trajanje zadržavaju istu funkciju, nekima se funkcija i „oblikovanje“ mijenjaju postupno i ovisno o kontekstu vremena, dok neki prostori prolaze izrazito dramatične, a katkad i teško razumljive preobrazbe.

Kao primjer za ovaj posljednji slučaj izdvojili bismo crkvu sv. Tome u Zadru. Prva trobrodna bazilika sagrađena je na ovome mjestu u 5. stoljeću (Uglešić 2002: 19-21). Prolazeći tijekom srednjega i ranoga novog vijeka kroz različite promjene u vanjskom izgledu i unutrašnjem uređenju kao i u titularima (sv. Toma Apostol, sv. Silvestar papa, sv. Križ) crkva je dočekala 1807. godinu kada je odlukom francuskih vlasti, kao i brojne druge u Dalmaciji, prestala biti u funkciji. Godine 1822. crkva je jednim dijelom porušena te je nad preostalim dijelovima sagrađena školska zgrada, a crkveni inventar je završio diljem Dalmacije. Tako su barokni kipovi sv. Silvestra i sv. Tome našli svoje mjesto u staroj crkvi Gospe od Zdravlja u Splitu da bi naknadno, 30-ih godina 20. stoljeća, završili u župnoj crkvi na Lovreću kod Imotskog, gdje se i danas nalaze. U Drugom svjetskom ratu spomenuta školska zgrada najvećim je dijelom porušena u teškom bombardiranju Zadra. U poslijeratnoj obnovi grada, tijekom nekoliko istraživačkih kampanja od 50-ih godina do 1972. godine pronađeni su ostaci ove crkve te dijelovi njezina kamenog namještaja, reljefi, nadgrobne ploče itd. Godine 1972. iznad ostataka crkve sagrađena je poslovna zgrada, a ostaci crkve su prezentirani su u njezinu prizemlju, iako ne onako kako je to zamišljeno i projektirano u suradnji sa zadarskim konzervatorima (Petricioli \& Vežić 1975). Dugo godina ostaci sv. Tome živjeli su u nekoj neprirodnoj simbiozi sa širokim asortimanom proizvoda poznate tvornice „Jugoplastika“ čija se trgovina nalazila u prizemlju zgrade. U tom istom prizemlju danas djeluje jedna strana banka (sl. 1a, b). Pitamo se nakon ovoga, kako bi danas izgledala susjedna crkva sv. Krševana, jedan od najvažnijih spomenika romaničke arhitekture u Hrvatskoj, da je sukladno odluci francuskih vlasti pretvorena u studentsku spavaonicu i podijeljena na prizemlje i kat (Kovačić 2011: 418). Ovdje smo iznijeli primjer jedne krajnosti, ali takvih je zasigurno mnogo više i ovdje ih je nemoguće sve nabrojiti. 


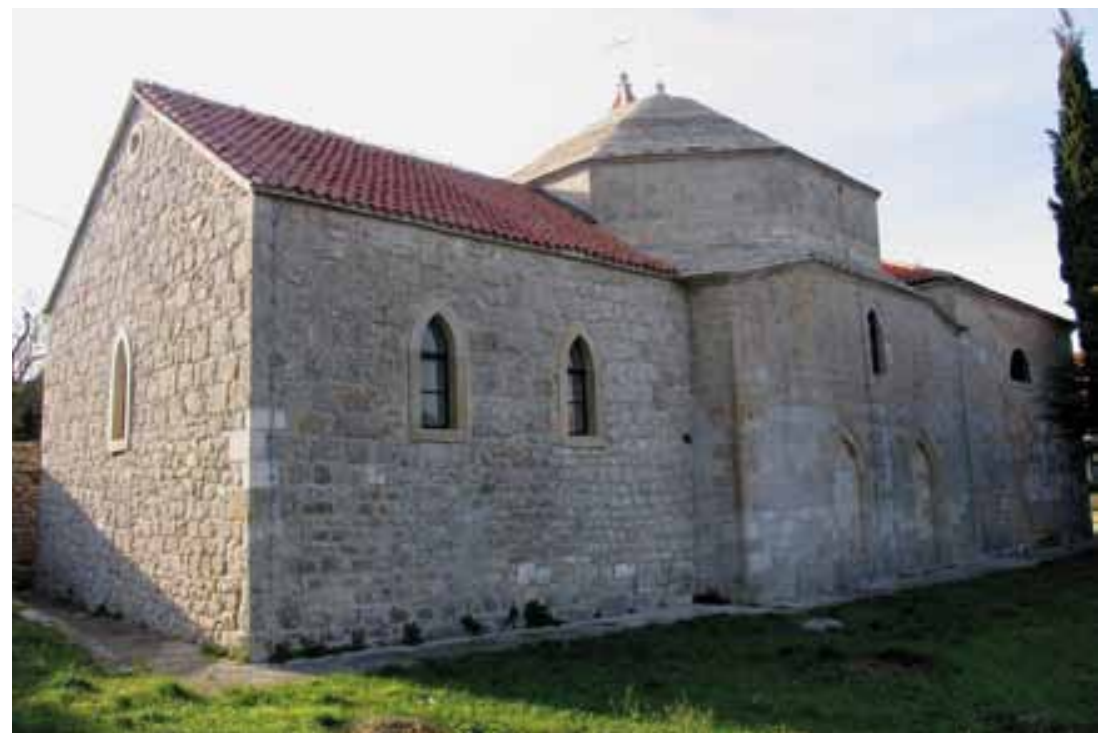

SI. 2: Drniš, crkva sv. Ante s bivšom džamijom u središnjem dijelu (fotografirao: I. Alduk).

Drukčiji primjer, rekli bismo snošljiviji, nalazimo u Drnišu. Tamošnja crkva sv. Ante zapravo je džamija iz 16. stoljeća - ali ovdje poznata i toliko puta viđena priča o konvertiranju crkve u džamiju ili obrnuto (Klis, Đakovo), ne staje (sl. 2). Džamiju je krajem 16. ili početkom 17. stoljeća sagradio Serasker Halil Hodža. Taj ugledni Drnišanin je 1616. godine visovačkim fratrima posudio 600 reala za gradnju novog samostana na obali Krke do čega na kraju nije došlo. Veći dio svoga života Halil Hodža se iskazao kao prijatelj i zaštitnik fratara, a na samrti je i pokidao zadužnicu za tih 600 reala te na taj način „onim siromašnim fratrima“ oprostio dug. Godine 1670. (trinaest godina prije prestanka osmanske vlasti u Drnišu) džamiju preuzimaju visovački fratri te ona postaje crkva sv. Ante, a kasnije je i nadograđuju prema istoku i zapadu te podižu zvonik.

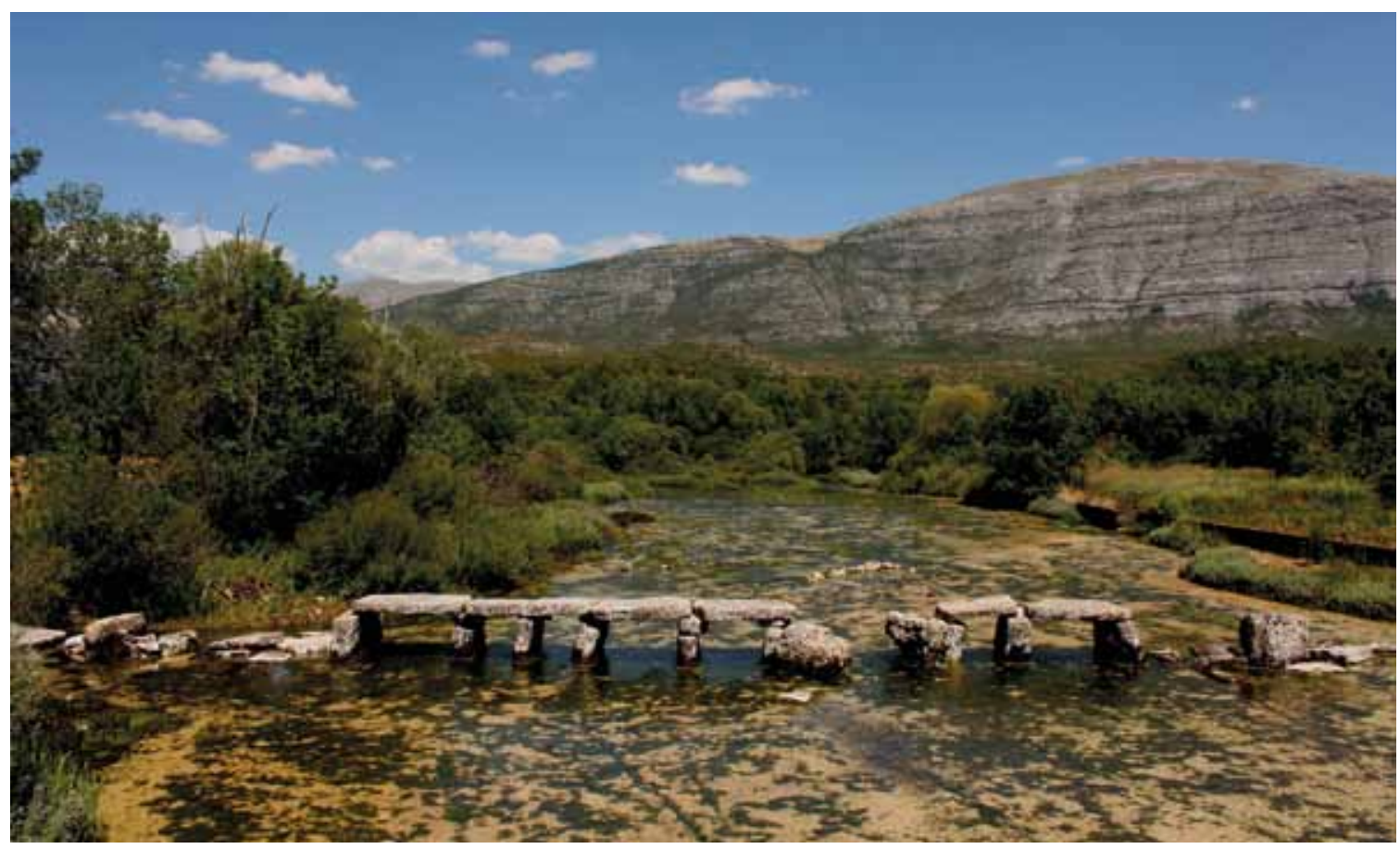

SI. 3: Izvor Cetine, Pločasti most (fotografirao: I. Alduk). 
SI. 4: Kljenak kod Vrgorca, crkva Svih Svetih, stećci u sjevernom zidu crkve (fotografirao: I. Alduk).

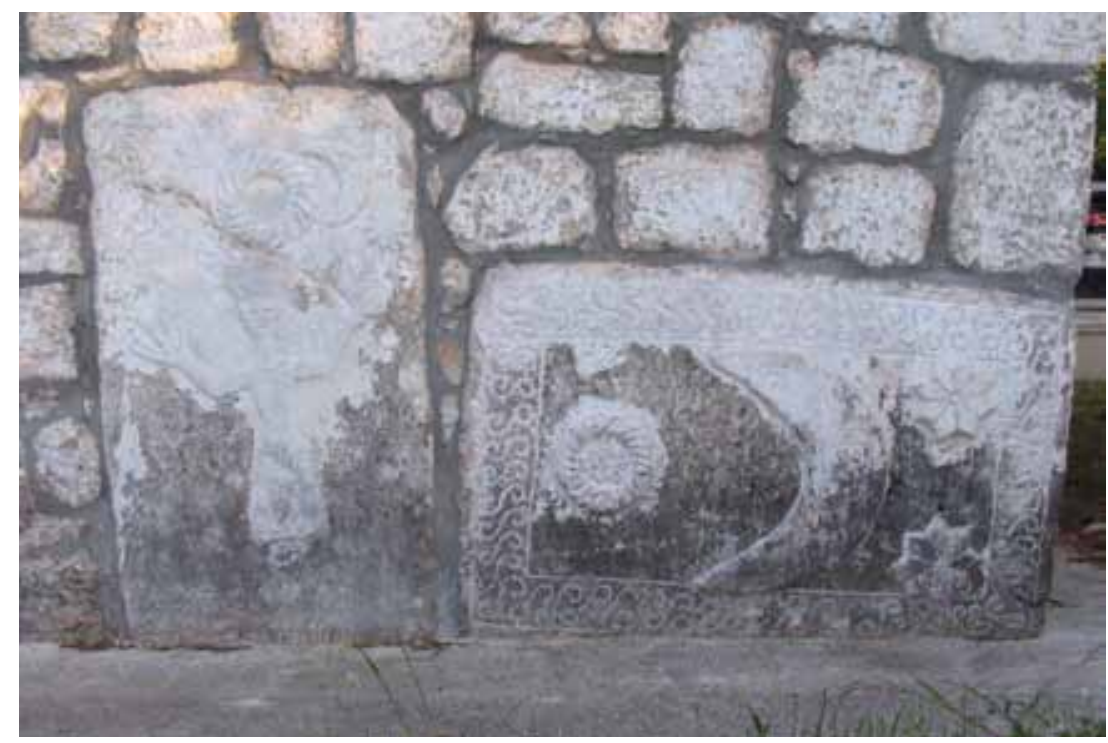

Možda će zazvučati naivno, ali lijepo je vjerovati da su se fratri vodili poštovanjem prema svom zaštitniku u njima nesklonim vremenima, čuvajući njegovu zadužbinu i uspomenu na njega. S druge strane, s jedne od drniških džamija, odnosno sahat-kule, mletačka je vojska u jednom od svojih napada na grad 1647. godine skinula sat koji i danas pokazuje vrijeme na zvoniku šibenske crkve sv. Ivana (Traljić 1972; Kosor 1979: 132; Jurin-Starčević 2006: 127, 134).

Nedaleko od izvora Cetine i poznate starohrvatske crkve sv. Spasa nailazimo na jedan drukčiji primjer „reciklaže“, ne toliko prostora koliko spomenika, točnije stećaka (sl. 3)! Naime, prostor oko izvora Cetine bio je tijekom srednjeg vijeka dio župe Vrhrike te gusto naseljen relativno bogatom populacijom čije grobove je Stipe Gunjača istražio oko spomenute crkve sv. Spasa. 0 njihovu bogatstvu govore nalazi iz tih grobova, od kojih se ističu raskošni parovi trojagodnih ili kruškolikih naušnica, a posebno poznati pozlaćeni pojas - remek-djelo domaćih zlatarskih srednjovjekovnih radionica (Jakšić \& Petrinec 1996). Negdje u 17. ili tijekom 18. stoljeća s jednog od srednjovjekovnih grobalja oko izvora Cetine (najvjerojatnije Preočanskog groblja kod zaseoka Vranješi) skinute su nadgrobne ploče te je od njih na plitkom gazu rijeke između Cetinskog i Vranješevog polja podignut most.

Nešto dalje, kod drugog izvora Cetine „Vukovića vrela“ također je podignut sličan most (Milošević 1998: 78, 87). Ova dva mosta su možda najoriginalniji primjer naknadne upotrebe stećaka. Naravno, gledajući iz današnje perspektive rekli bismo da se radi o devastaciji spomenika. Pišući o stećcima, nemoguće je izbjeći i priču o „reciklaži“ tih spomenika s obzirom na to da oni u jednom trenutku postaju običan građevinski materijal za gradnju (spoliji), u prvom redu crkava i oltara, ali i kuća, pojata, bunara, kamenica za vodu. To se najčešće događa tijekom 17. ili 18. stoljeća, u trenutku kada blijedi značenje stećaka za lokalno stanovništvo ili se na pojedine prostore doseljava novo stanovništvo koje više nema određeni odnos prema stećcima. Crkve Svih Svetih u selu Kljenak i sv. Ivana u Stilji kod Vrgorca sagrađene su velikim dijelom od stećaka (sl. 4) - ali ti su stećci jedni od najljepših koji se nalaze na prostoru Dalmacije i koji pripadaju posebnoj radionici (ili majstoru „kovaču“) koja je tijekom 14. i 15. stoljeća djelovala u ovom dijelu Zabiokovlja (Alduk 2011).

S druge strane, crkva sv. Luke na Kamenmostu kod Imotskog većim dijelom je sagrađena od stećaka kojima su uklonjeni gotovo svi ukrasi osim križeva, s obzirom na to da je prema njima postojalo određeno poštovanje (sl. 5). Govoreći o toj crkvi važno je naglasiti i njezinu prenamjenu. Crkva je sagrađena 1705. godine (na mjestu starije) u neposrednoj blizini još uvijek turskog 


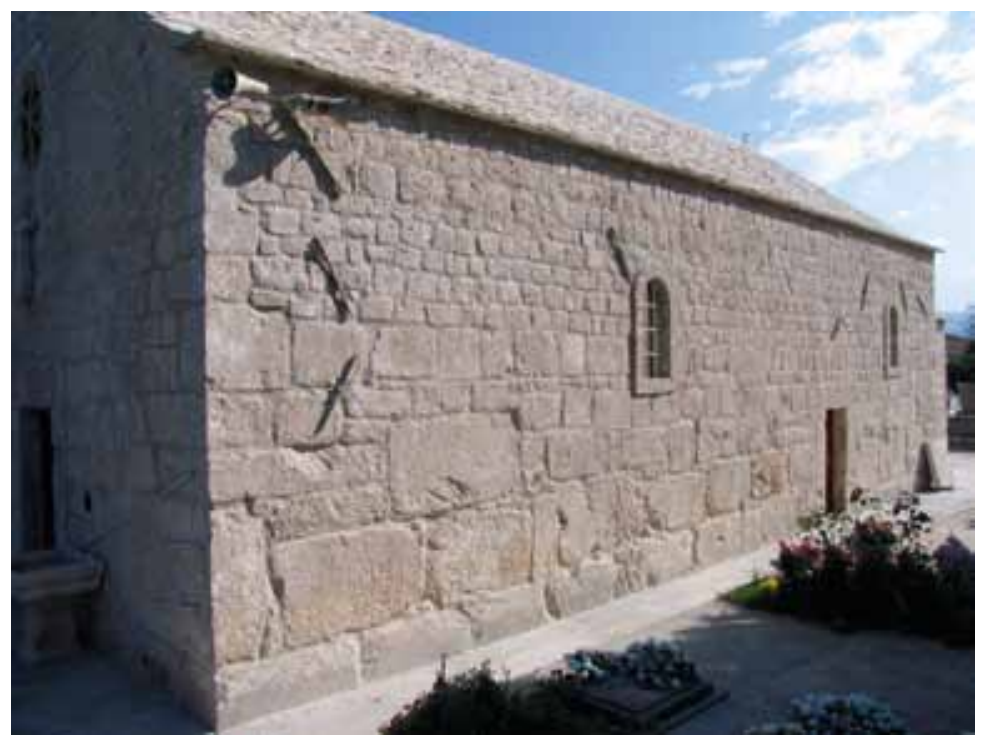

SI. 5: Kamenmost kod Imotskog, crkva sv. Luke, stećci u južnom zidu crkve (fotografirao: I. Alduk).

Imotskog. Okolnom kršćanskom stanovništvu je osim kao crkva služila i kao utvrda s izrazito širokim zidovima i kamenim svodom pokrivenim krovom od kamenih ploča. U to je doba crkva imala vrlo uska vrata te nije imala drugih otvora osim puškarnica koje su otkrivene u posljednjim zaštitno-istraživačkim radovima.

U dalmatinskom krajoliku, svojom se brojnošću i smještajem ističu kamene gomile - prapovijesni tumuli. Mišljenja smo da ukoliko bi postojao konačni broj arheoloških lokaliteta na ovom prostoru, onda bi barem polovica od toga broja otpadala na prapovijesne gomile. S obzirom

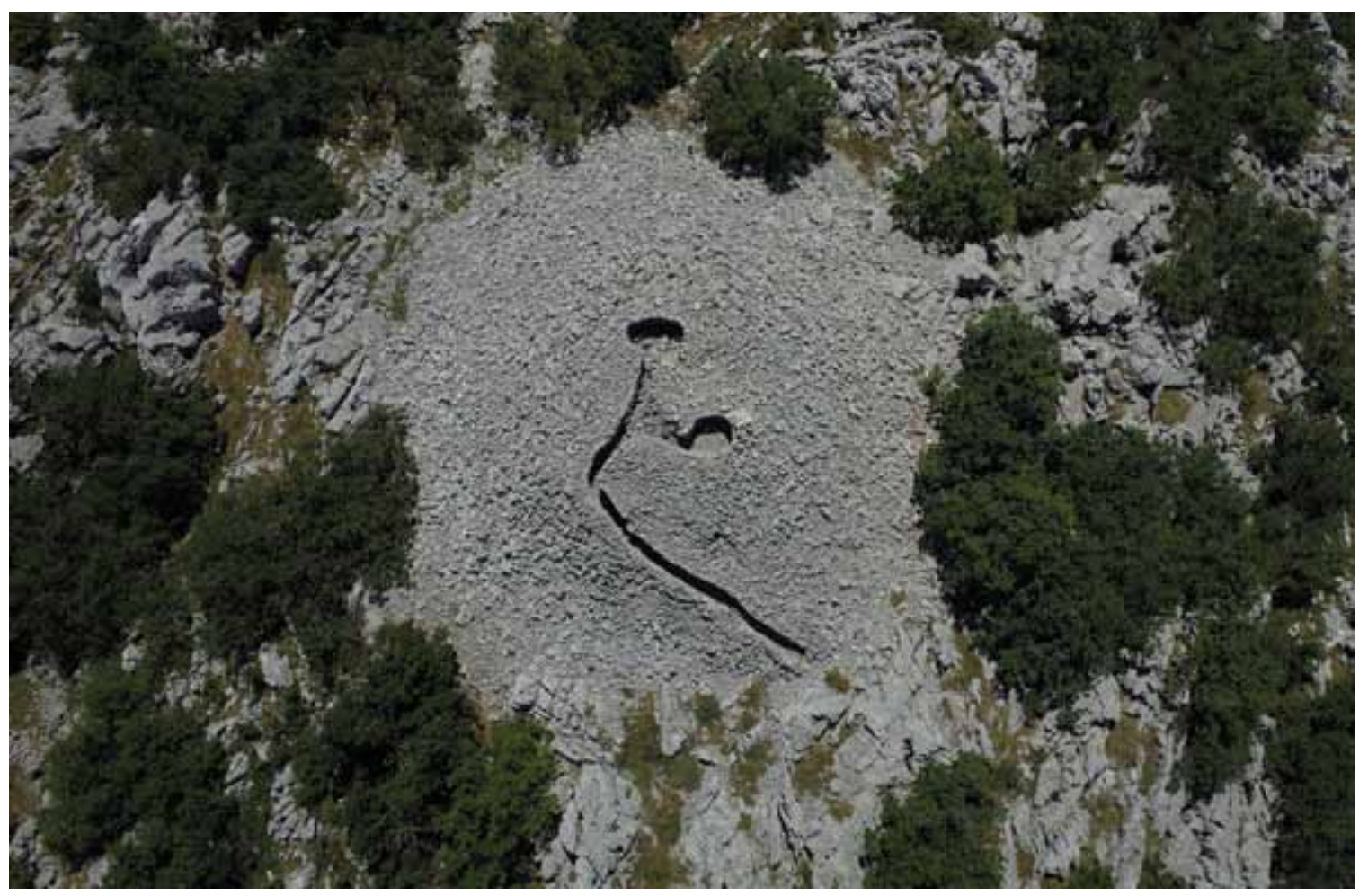

Sl. 6: Biokovo, Podglogovik, prapovijesni tumul s kasnijim intervencijama (fotografirao: M. Vuković). 


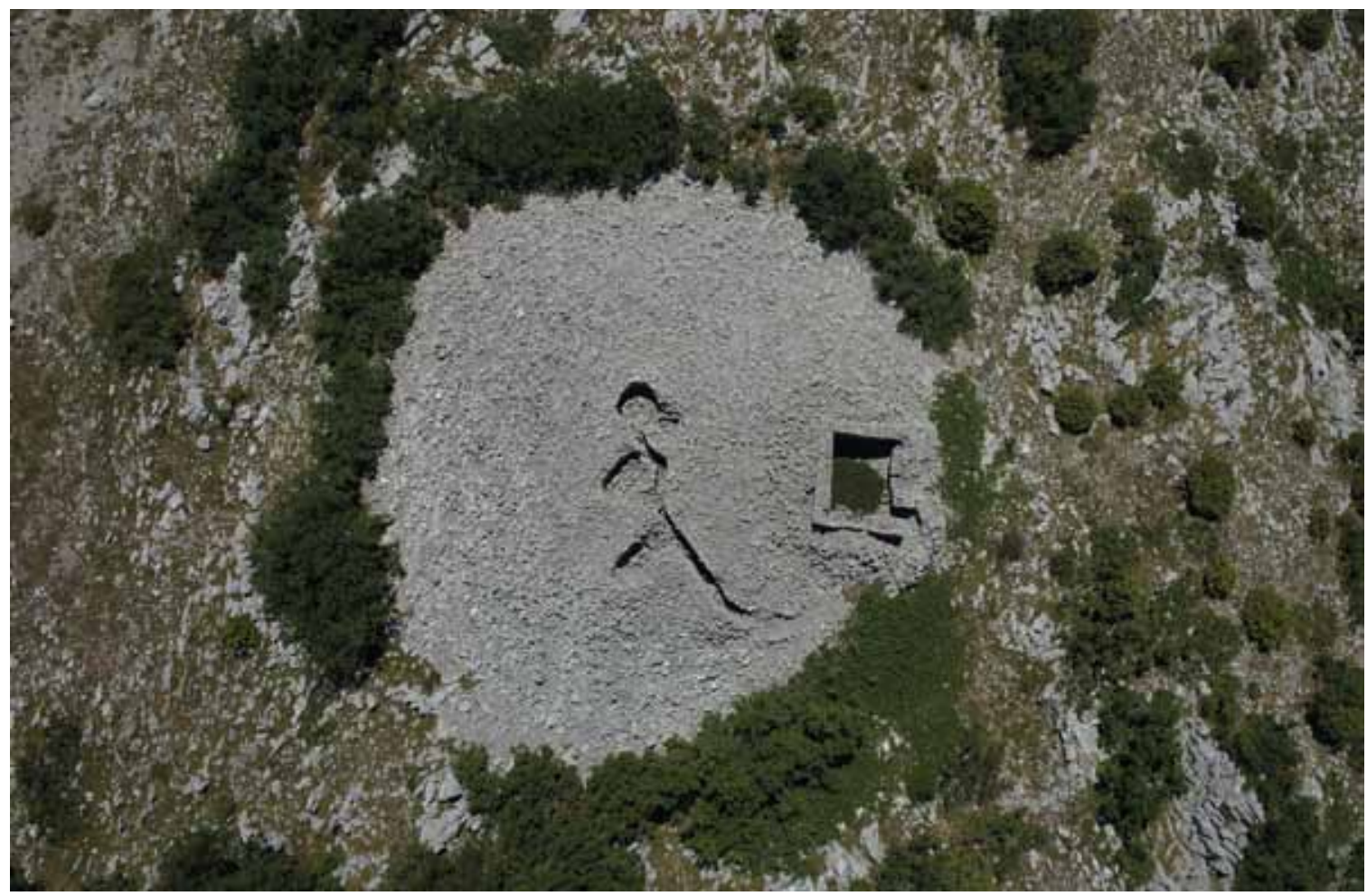

na brojnost i njihov geografski smještaj nije ni čudo što su tijekom povijesti upotrebljavane na najrazličitije načine. Jedan od zanimljivijih i relativno novijeg datuma nepoznat je u stručnoj literaturi, a sačuvan je na Biokovu kod pastirskog stana Podglogovik! Podglogovik je povremeno naselje stočara iz Podgore koji su sušniji dio godine provodili na planini na nadmorskoj visini od oko 900 m i više (Mihić 1986: 159-169). Godine 1878. južnije od Podglogovika preko prijevoja „Staza“ austrijska vojska probila je cestu koja je vezivala Makarsko primorje i Zabiokovlje, te se u selu Kozici kod Vrgorca spajala s tamošnjom „napoleonskom“ cestom - glavnom komunikacijom kroz unutrašnjost ovoga dijela Dalmacije do izgradnje suvremenog autoputa. Cesta je dobila ime „Rodićeva cesta“ prema dalmatinskom namjesniku barunu Gabrijelu Rodiću koji se uvelike zalagao za njezinu gradnju smatrajući je strateškom komunikacijom prema još uvijek turskoj Bosni i Hercegovini (Piplović 2003). Iako je cesta u međuvremenu ponešto izgubila na važnosti, tijekom Prvoga svjetskog rata upravo je kod Podglogovika i prijevoja „Staza“ cesta utvrđena u slučaju neprijateljskog prodora prema obali - i to na zanimljiv način! Uokolo doline oko koje se smjestio Podglogovik, odnosno s njezine istočne, južne i zapadne strane sačuvano je 20-ak prapovijesnih gomila. Na najvećoj i najistaknutijoj koja se nalazi na samom početku „Staze“ sagrađena je krajem 18. stoljeća crkvica sv. Ilije. Prema sačuvanoj narodnoj predaji ovdje je 1807. godine došlo do sukoba Podgorana (i ostalih stanovnika Makarskog primorja) s francuskom vojskom (Šunde 1999: 167, 179, 183). Strateška važnost puta preko „Staze“ i ovdje dolazi do izražaja. Stoga će više od stotinu godina kasnije austrijske vlasti utvrditi ovaj prijevoj i to služeći se upravo prapovijesnim gomilama (sl. 6, sl. 7). Na prvi takav primjer nailazimo uz tzv. „Topnički put“, koji od spomenute crkvice vodi prema istoku i uz koji su u kamen živac ukopani rovovi. Otprilike $400 \mathrm{~m}$ jugoistočno od crkvice, u prapovijesnu gomilu smještenu gotovo na rubu litice, ukopana je i od kamena slaganog u suho izgrađena manja nastamba uz koju je bunar za skupljanje vode. Istočno i južno od Podglogovika u dužini od oko jednog kilometra po 
rubu uzvisine smjestilo se 15 -ak većih i manjih prapovijesnih gomila. Posebno su zanimljive dvije najveće smještene iznad „Velike lokve“. Gomile su promjera 25-30 metara i visine 4-5 metara. U obje su naknadno ukopani kanali širine oko 0,6 metara koji vode gotovo do središnjeg dijela gomile u kojem se račvaju na dva ili tri nešto šira prostora, također ukopana u gomilu do oko 1,3 metara dubine. Na južnom rubu sjevernije gomile sagrađena je i dijelom u gomilu ukopana suhozidna kućica dimenzija oko 4x6 metara s vratima i prozorom na južnoj strani. Opisani kanali i proširenja u središnjem dijelu gomile izgledaju kao rovovi s tim da su proširenja u gomili okrenuta prema jugu i istoku. Na taj način iz sigurnosti kamene gomile savršeno se nadzire cesta koja sa „Staze“ nastavlja dalje prema istoku, odnosno „Saranču“. Ove intervencije uokolo „Staze“ trebalo bi dovesti u vezu s akcijama austro-ugarske vojske da krajem 1915. i početkom 1916. godine utvrde dijelove Makarskog primorja u strahu od napada englesko-francuske mornarice ili eventualnog prodora neprijatelja iz zaleđa (Urlić 2007: 39-40).

Dva izuzetna, ali rijetko spominjana, primjera „recikliranje“ prostora nalazimo na Braču i Šolti. U Škripu na otoku Braču nalazi se sklop „Radojković“ u kojem je danas smješten Brački muzej. Sklop se sastoji od dvije jednokatnice i trokatne kule na zapadu s ograđenim dvorištem. Čitav sklop nastaje na prapovijesnim bedemima Škripa od kojih je dio zidan i tzv. megalitskom tehnikom i vjerojatno pripada helenističkom razdoblju. Posebno je zanimljiva visoka trokatna kula koja dominira cijelim sklopom (Faber \& Nikolanci 1985). Prizemlje kule građeno je od većih blokova, a iznutra je presvođeno kamenim svodom. Radi se vjerojatno o mauzoleju jednog od bogatijih otočana koji je živio u ranoantičkom razdoblju (sl. 8).

Izgleda da se mauzolej pretvara u kulu unutar novih bedema naselja već u kasnoj antici. Kasnije je naselje doživjelo određene promjene da bi bračka obitelj Radojković krajem 16. stoljeća nadogradila opisani mauzolej-kulu te su je dodatno povisili i utvrdili, strahujući od pljačkaških pohoda Turaka s obližnjeg kopna ili pak iznenadnih gusarskih napada (sl. 9).

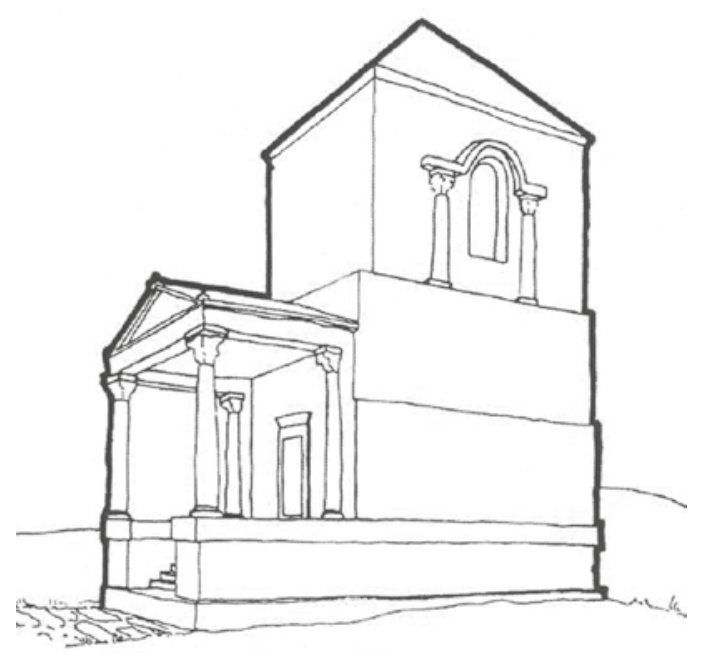

SI. 8: Škrip, Kaštel Radojković, rekonstrukcija antičkog mauzoleja (Faber \& Nikolanci 1985: 18).

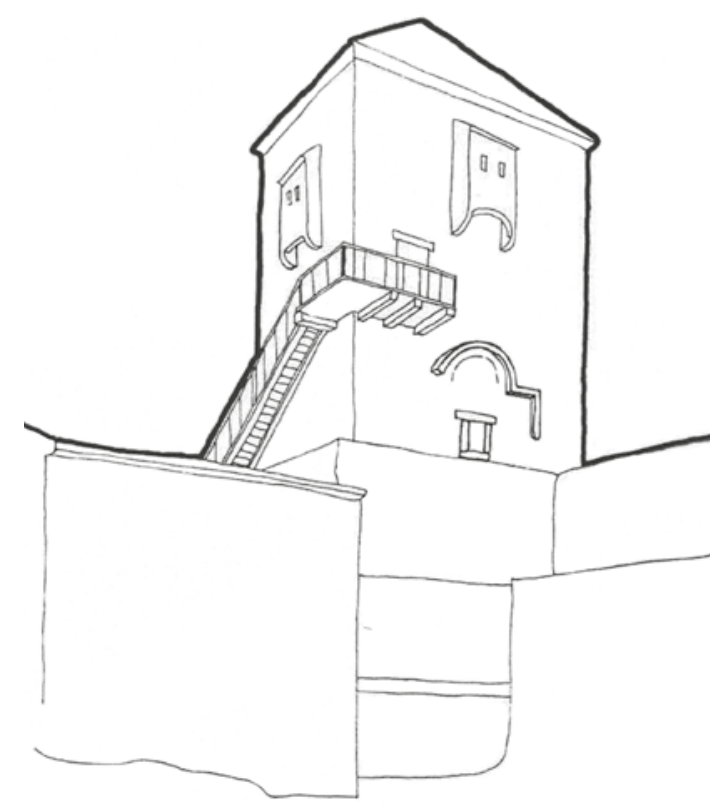

SI. 9: Škrip, Kaštel Radojković, rekonstrukcija srednjovjekovne kule na antičkom mauzoleju (Faber \& Nikolanci 1985: 18). 


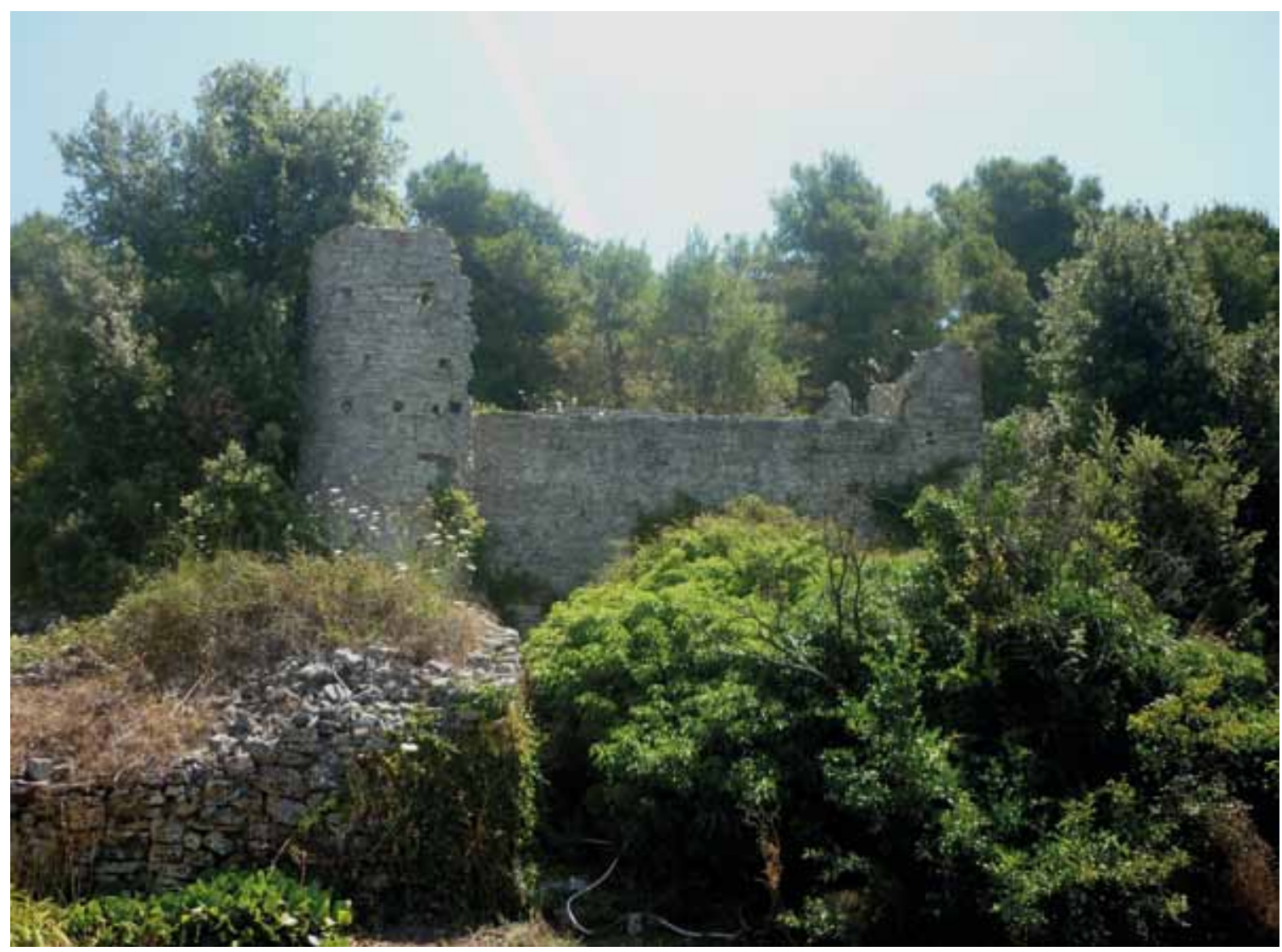

Drugi primjer nalazimo na Šolti, otoku rijetko prisutnom u znanstvenoj literaturi. Sjeverno od Gornjeg Sela u neposrednoj blizini crkve i groblja Gospe od Stomorije nalazi se lokalitet "Starine" - jedno od najintrigantnijih arheoloških nalazišta u Dalmaciji (Mihovilović 1990: 56, 61). Na ovom mjestu sačuvana je utvrda visine zidova i preko 6 metara. Utvrda ima najmanje četiri faze gradnje, tj. uporabe (sl. 10). Prva faza predstavlja vjerojatno ranoantički (rimski) stambeno-gospodarski objekt sačuvan u arheološkim tragovima oko današnje utvrde. U vrijeme kasne antike, na što nas upućuju sačuvani gljivasti otvori na zidovima, nastaje stambeni objekt s cisternom za vodu sačuvan danas gotovo u izvornim gabaritima do visine od oko 5 metara. Treća faza gradnje uslijedila je tijekom srednjega ili ranoga novog vijeka. Kasnoantičkoj građevini na "Starinama" tada su na sjeverozapadnom i jugoistočnom uglu dodane dvije okrugle kule s puškarnicama za lakšu obranu. Naime, Šolta je često bila na meti gusarskih, a kasnije i turskih napada. U današnje vrijeme (ili barem donedavno) utvrda je još uvijek služila za privremeni boravak ljudima i životinjama, a cisterna sačuvana unutar objekta i danas skuplja i drži kišnicu koja služi za zalijevanje okolnih polja.

Ovu priču, koju je uistinu teško svesti na nekoliko stranica, završit ćemo nešto drukčijim ali gotovo svima poznatim prostorom i spomenikom. Na otoku Hvaru, u Starogradskom polju, ravnici između Starog Grada (grčki Faros) i Vrboske, nalazi se najbolje sačuvana grčka podjela zemljišta na Sredozemlju, tzv. Farska hora - Xo $\alpha$ $\Phi \alpha \rho o u$ (Duboković 1969: 91-97; Ager Pharensis 1993; Zaninović 1996: 28-33; Slapšak 2002: 195-220, sa svom relevantnom litera- 


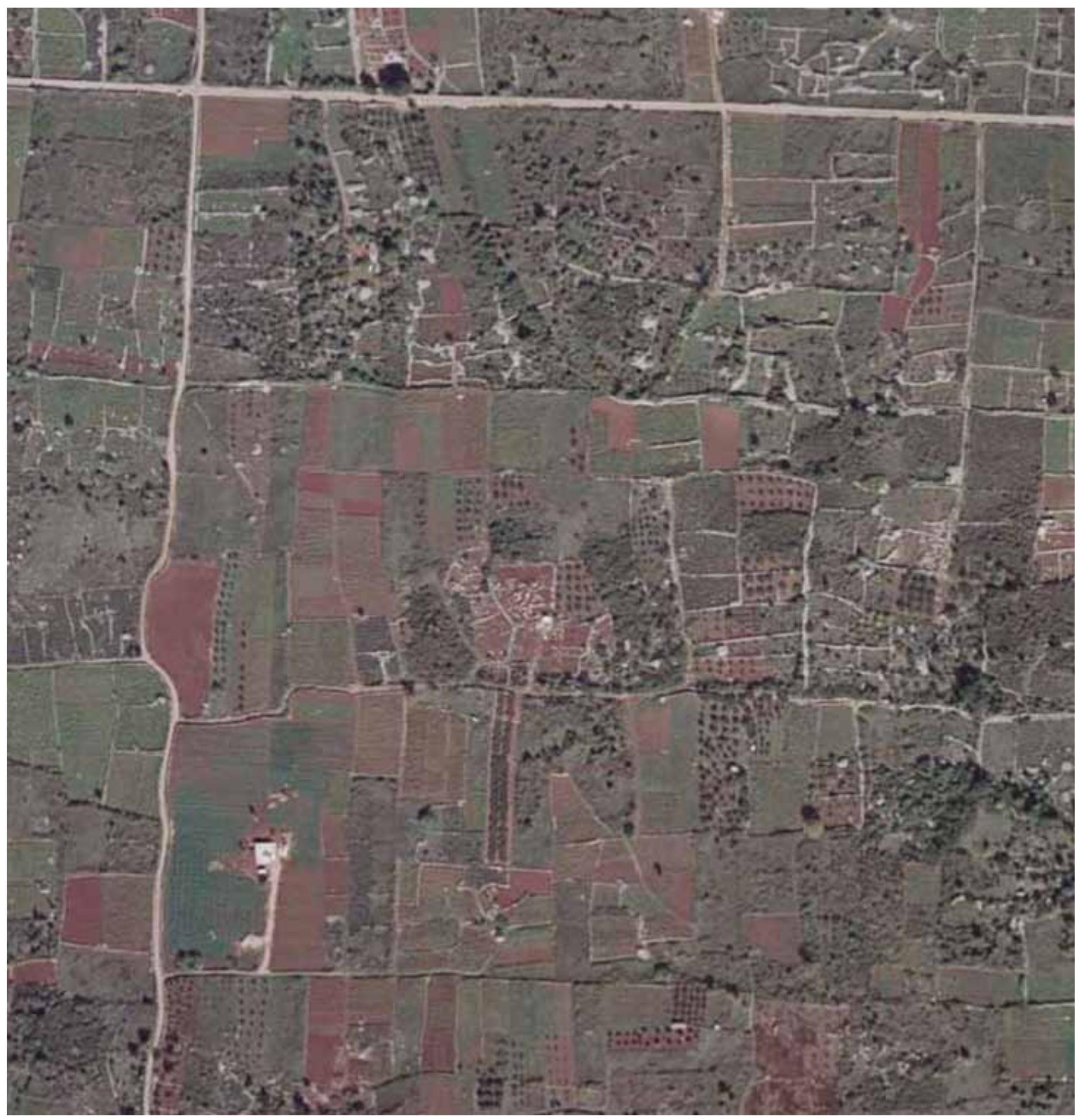

turom). Iz više razloga taj prvorazredni starogrčki katastar je od 2008. godine na UNESCO-voj Listi svjetske baštine (sl. 11). Unatoč tome, taj prostor nikada nije obrađen publikacijom koja bi se, osim njegovim nastankom, detaljno bavila i njegovim razvojem u posljednjih 2400 godina. Jer priča je tek započela u trenutku kada su doseljenici s egejskog Parosa podijelili ovo polje u 70-ak identičnih parcela (hora) dimenzija 1x5 stadija, tj. 180x900 metara. Rimljani će Farosu 


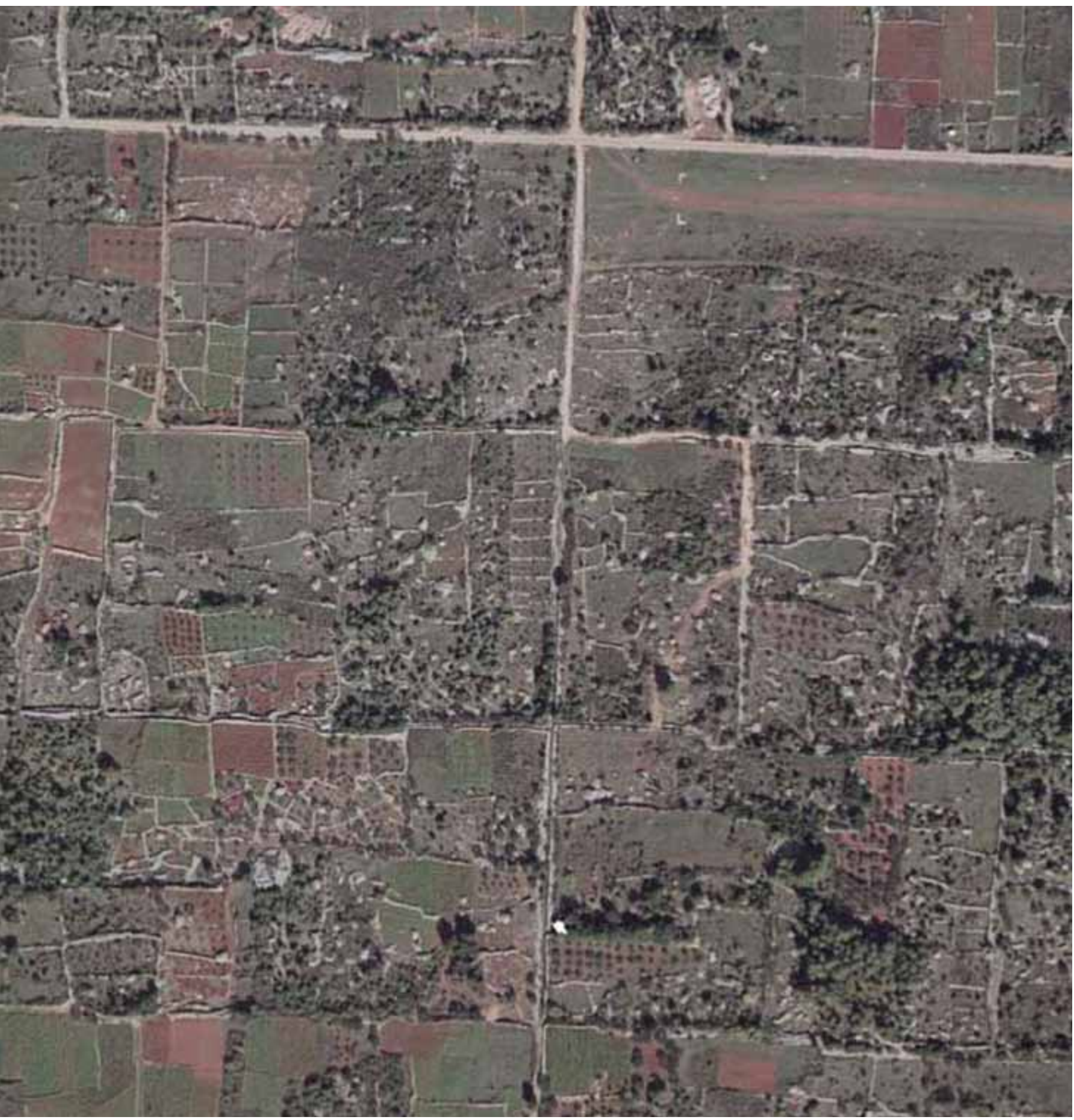

promijeniti ime u Farija (Pharia). Poslovično praktični, oni će zadržati stariju podjelu zemljišta, iako će u isto vrijeme prostore oko kolonija na obali (Pula, Zadar, Salona) premrežiti svojom centurijacijom, drugačijom od one grčke na Hvaru. Ipak, doći će do promjena, pa će se u polju na nekoliko mjesta graditi različiti stambeni i gospodarski objekti koje danas, katkad i pretenciozno, nazivamo vilama - Kupinovik, Carevac, Ježe, Mirje, Ivončeve njive i dr. 
Nove podjele zemljišta uslijedile su u srednjem vijeku kada se polje zove "Polje sv. Stjepana i Vrbanja" - dakle, pod zaštitom je patrona hvarske biskupije čije je sjedište do sredine 13. stoljeća bilo u Starom Gradu, a onda je preseljeno u Hvar. Velike zemljišne posjede u polju tada drži hvarska biskupija. Ono je posuto toponimima izrazito slavenskog podrijetla što također govori o velikim promjenama koje su u ranom srednjem vijeku zadesile taj dio otoka. Po podacima hvarskog srednjovjekovnog statuta "Polje sv. Stjepana" premreženo je putevima u smjeru istok-zapad i sjever-jug - sudeći prema opisima većina puteva očito prate grčke pravce podjele zemljišta i starije puteve (Statut 1991: 153-158; Petrić 2015: 213). Naravno, podjele su se nastavile i u kasnijim razdobljima, zemlja usitnjavala i dijelila u sve manje parcele. Ali ono što je bitno naglasiti, sve ove naknadne podjele zemljišta i promjene u polju događale su se uvijek unutar izvornih grčkih parcela od 180x900 metara, što ih je sačuvalo do današnjeg dana. U tom smislu ponovo bismo upozorili na Dubokovićev rad i kartu koju on donosi (Duboković 1969), a na kojoj se razaznaju upravo te kasnije podjele od kojih su neke vrlo pravilne i kvadratnog oblika (što je ovog autora navelo da iznese, kako je kasnije utvrđeno, pogrešnu ideju o rimskoj centurijaciji polja). S druge strane, očito je da su se unutar polja događale i drugačije promjene - posebice izražene u posljednjim desetljećima. Naime, tijekom stoljeća došlo je do promjene poljoprivrednih kultura koje su se u polju uzgajale kao i načina obrade zemlje. Pretpostavljamo da je u grčko (helenističko) doba naglasak bio na žitaricama - koje su bile od izuzetne važnosti za tadašnje stanovništvo Farosa. Posebice se to odnosi na središnji dio polja. Vodeći se ovom pretpostavkom, one druge kulture koje najčešće zamišljamo u mediteranskom pejzažu (loza, maslina, smokva i sl.) smjestili bi na padine oko polja. Upravo su žitarice (pšenica i ječam) izravno povezane s možda i najvažnijim kultom u grčkom Farosu (i njihovom matičnom otoku Parosu) - onom Demetre i Perzefone (Jeličić \& Katić 2015: 117-124, 131-134). Tijekom srednjeg vijeka očito je došlo do velikih promjena. Naime, prema nekim podacima iz 16. stoljeća, hvarska komuna samostalno je podmirivala svoje potrebe za žitom za samo dva mjeseca godišnje (Statut 1991: 18). Svo ostalo žito se uvozilo, a Statutom je određena i kazna za svakog stanovnika otoka kojega se uhvati da je uvezeno žito prodavao negdje drugdje, a ne u Hvaru (Statut 1991: 184-185 - knj. V, gl. XLIV). U isto vrijeme otok je proizvodio ogromne količine vina koje su bile gotovo glavni izvor prihoda komune (Statut 1991: 18). Iako je danas poznat po vinima, na Hvaru se sve više razvija i maslinarstvo pa se i velike površine u Starogradskom polju prenamijenjuju u maslinike. Ne ulazeći u razloge takvih promjena i njihovu opravdanost, činjenica je da novi načini obrade poljoprivrednih zemljišta uključuju i korištenje mehanizacije kao i maksimalno iskorištavanje zemljišta. Mehanizacija je često vrlo agresivna prema suhozidima i pristupnim putevima koji su se razvijali stoljećima. Na taj način postupna "reciklaža" prostora, koja je u slučaju "starogradske hore" trajala stoljećima, polagano ali sigurno postaje devastacija. Nestaju u prvom redu grčki pravci podjele polja, ali i svi oni kasniji koje još uvijek nismo dovoljno i kvalitetno istražili. Upravo je čuvanje krajolika najteži posao konzervatorske službe (Bilušić 2015), ali samo zbog gomile apsurdnih pravnih propisa koji taj posao nepotrebno otežavaju. S druge strane, u smislu profesionalnog izazova te pomirenja suvremenih potreba i principa zaštite spomenika, radi se vjerojatno o najizazovnijem segmentu konzervatorskog posla.

„Recikliranje“ određenog prostora najuže je povezano s njegovom slojevitošću. Upravo su višeslojni prostori i lokaliteti oni koji nas svojom raznolikošću i bogatstvom uvijek iznova iznenade. Gledajući očima konzervatora, neovisno o struci (arheologija, povijest umjetnosti, etnologija, arhitektura), takvi prostori su uvijek najteži pa stoga i najzanimljiviji za interpretaciju i valorizaciju. Profesionalni je izazov istraživati ih i pokušati za svako određeno razdoblje odrediti funkciju jednog prostora i kontekst u kojem se on razvija. Rezultati toga rada nas na kraju ipak obogate novim znanjem i iskustvom, vraćajući na taj način sav uloženi trud. 


\section{Literatura}

Ager Pharensis 1993. Posebni otisak iz časopisa Mogućnosti 1-2. 1993.

Alduk, I. 2011. „Kovač“ iz Gorske župe. Prilozi povijesti umjetnosti u Dalmaciji 42. Split. 161-203. Dumbović Bilušić, B. 2015. Krajolik kao kulturno naslijeđe. Ministarstvo kulture RH. Zagreb.

Duboković-Nadalini, N. 1969. Ager pharensis, arheološke bilješke. Vjesnik za arheologiju i historiju dalmatinsku LXIII-LXIV (1961-1962). Split. 91-97.

Faber, A. \& Nikolanci, M. 1985. Škrip na otoku Braču (naselje i spomenici prethistorijskog i antičkog doba). Prilozi Instituta za arheologiju u Zagrebu 2 (1). Zagreb. 1-38.

Jakšić, N. \& Petrinec, M. 1996. Kasnosrednjovjekovno groblje kod crkve sv. Spasa u Vrh Rici. Starohrvatska prosvjeta 23. Split. 139-172.

Jeličić Radonić, J. \& Katić, M. 2015. Faros - osnivanje antičkog grada. Književni krug Split. Split. Kovačić, S. 2011. Licej u Nadbiskupskom sjemeništu u Splitu i njegov teološki studij. U: Dalmacija za francuske uprave (1806.-1813.). (ur. M. Trogrlić \& J. Vrandečić). Split. Filozofski fakultet Split. 411-429.

Kosor, K. 1979. Drniška krajina za turskog vladanja. Kačić XI. Split. 125-182.

Jurin-Starčević, K. 2006. Islamsko-osmanski gradovi dalmatinskog zaleđa: prilog istraživanju urbanog razvoja u 16. i 17. stoljeću. Radovi Zavoda za hrvatsku povijest Filozofskog fakulteta u Zagrebu 38. Zagreb. 113-154.

Mihić, Lj. J. 1986. Biokovo - biseri prirode. Podgora.

Mihovilović, M. A. i suradnici 1990. Otok Šolta. Šolta - Zagreb.

Milošević, A. 1998, Arheološka topografija Cetine. Muzej hrvatskih arheoloških spomenika. Split.

Petricioli, I. \& Vežić, P. 1975. Izvještaj o istraživanju i konzervaciji ostataka bazilike sv. Tome u Zadru. Godišnjak zaštite spomenika kulture Hrvatske 1. Zagreb. 101-110.

Petrić, N. 2015. Zavičaju Hvaru. Književni krug Split. Hvar-Split.

Piplović, S. 2003. Cesta baruna Rodića. Makarsko primorje 6. Makarska. 121-129.

Slapšak, B. 2002. Nova opažanja o parcelaciji Chore Farosa. U: Grčki utjecaj na istočnoj obali Jadrana. (ur. N. Cambi, S. Čače, \& B. Kirigin). Književni krug Split. Split. 195-212.

Hvarski statut. 1991. Književni krug. Split.

Šunde, S. 1999. Narodna predaja o ustanku Primoraca protiv Francuza. Makarsko primorje 4. Makarska. 135-158.

Traljić, S. M. 1972. Drniš šestaestog i sedamnaestog stoljeća. Radovi JAZU Zadar 19. 393-402.

Uglešić, A. 2002. Ranokršćanska arhitektura na području Zadarske biskupije, Filozofski fakultet Zadar/Zadarska nadbiskupija. Zadar.

Urlić, V. 2007. U spomen 1914-1918 - Makarsko primorje. Gradski muzej Makarska. Makarska. Zaninović, M. 1996. Od Helena do Hrvata. Školska knjiga. Zagreb. 